\title{
Research on the Innovative Artistic Talent Training of Universities in Liaoning with the Background of Cultural Creativity
}

\author{
Xin Tao \\ School of Art \\ He University \\ Shenyang, China 110163
}

\author{
Xuefeng Shi \\ School of Art \\ He University \\ Shenyang, China 110163
}

\author{
Shuxin Wang \\ School of Art \\ He University \\ Shenyang, China 110163
}

\begin{abstract}
Located in the northeast China, Liaoning province has been the important transportation junction since ancient times. Meanwhile, it has abundant urban culture and diversified arts as well as prominent comprehensive strength in science and education. It not only lays a solid foundation for Liaoning area to vigorously develop the cultural industry but also provides superior conditions for the cultural industry progress. At present, the art and culture industry has developed into the important economic growth point of Liaoning province and one of the mainstay industries. However, the development level and quality of cultural industry in Liaoning don't correspond to the decisive position of old industrial bases of Liaoning and the growing demands of cultural consumption, because cultural and artistic talents are lack in Liaoning, especially the innovative talents of cultural industry in quantity and quality. Currently, the research achievements on culture creativity, the training of artistic talents in universities and the innovation and entrepreneurship education have been abundant, but because the cultural creative industry is one of the emerging industries in the new century, the research on it is still at the initial stage and immature in our country, lacking ready-made theories. There is no related research in Liaoning province. This paper analyzes the environment of culture creativity, explores and summarizes the strategies to train innovative artistic talents in Liaoning area through investigation and analysis on universities in Liaoning province, looking forward to providing theoretical guidance and reference for the training of innovative artistic talents in universities of Liaoning area.
\end{abstract}

Keywords-culture creativity; universities in Liaoning; talents training

\section{INTRODUCTION}

Culture is the connotation of all artistic forms, but art cannot totally represent culture. Art is only a tool and means to

This paper is the 2016 Liaoning Province economic and social development project approval research achievement, project title: Research on the Innovative Artistic Talent Training of Universities in Liaoning under the Background of Culture Creativity, project number: 20161slktwx-13. spread culture. Although art and culture have different internal essence, they have necessary connections.

The soaring development of cultural creative industry of our country provides opportunities for the development of artistic talents with innovation consciousness in the new era at the meantime has higher requirements for the training of innovative talents especially artistic talents. Under this background, Liaoning province quickens the pace in training creative talents of universities. In 2015, the People's Government of Liaoning Province issued the Implementation Plan on Deepening the Reform of Innovation and Entrepreneurship Education in General Institute of Higher Education. The newly-issued nine measures are to promote the educational reform of universities in Liaoning to guarantee the quality of talent education and training. Besides, it lays a solid foundation for the recovery and revitalization of northeast old industrial base and the further implementation of the national innovative development strategy.

However, few can reasonably apply the mechanism and ways to the training and education of talents in art and design and summarize the feasibility demonstration with characteristics of Liaoning and conforming to the features of universities in Liaoning. At present, on the basis of innovative thinking, most researchers only discuss the importance of innovation and the learning methods. The training of art and design innovation ability must depend on a lot of practice, so as to train and verify students' innovative learning outcomes and innovation ability.

\section{THE BACKGROUND OF ARTISTIC INNOVATIVE TALENT TRAINING IN UNIVERSITIES OF LIAONING}

Located in the northeast China, Liaoning province has been the important transportation junction since ancient times. Meanwhile, it has abundant urban culture and diversified arts as well as prominent comprehensive strength in science and 
education. It not only lays a solid foundation for Liaoning area to vigorously develop the cultural industry but also provides superior conditions for the cultural industry progress. At present, the art and culture industry has developed into the important economic growth point of Liaoning province and one of the mainstay industries.

However, the development level and quality of cultural industry in Liaoning don't correspond to the decisive position of old industrial bases of Liaoning and the growing demands of cultural consumption, because cultural and artistic talents are lack in Liaoning, especially the innovative talents of cultural industry in quantity and quality. It shows as follows:

Lack innovative talents. Although Liaoning has unique regional culture, the artistic talents don't have enough innovation consciousness and innovative impetus and cannot integrate the excellent local culture in the artistic creation, resulting in low popularity and recognition degree of regional culture of Liaoning.

It's hard to find compound talents. The cultural media industry of Liaoning doesn't lack outstanding designers, but it is hard to find talents with culture creativity and the ability of art and design.

The industrial structure is unreasonable. The cultural creative industry in Liaoning has a late start. The knowledge structure of employees and the structure in the industry remain to be optimized and adjusted.

In order to solve problems of talent training in the cultural industry, it needs the coordination of government sectors and universities to promote the reform of talent training mode, providing talents for the development of cultural industry.

\section{ANALYSIS ON THE CURRENT SitUATION OF ARTISTIC} INNOVATIVE TALENT TRAINING IN UNIVERSITIES OF LIAONING

\section{A. Source of Students}

In recent years, with the continuous development of social economy and the improvement of cultural needs, the training of talents major in art of universities in Liaoning is also expanded rapidly. The competition between universities is also increasingly fierce. Some specialties are restricted even forbidden to enroll students. Students have weak cultural basis because of the extra learning of art. They cannot grasp the basic knowledge of art major and understand the basis of art and culture.

\section{B. University System}

According to the scale and history of schools, universities training artistic talents can be divided into professional art colleges (like the key college of fine arts), comprehensive universities (like normal universities) and private colleges.

\section{Major Setup}

At present, with the rapid development of cultural market and the reinforcement of the education capacity of art colleges, many universities have provided specialties of art and design as well as film and TV specialty like animation and media. The major setup is careful and comprehensive. But with the continuous change of culture creativity market and the emergence of new virtual and reality technology, the major setup is backward, unsuitable for the developing cultural industry and expanding market demands.

\section{Teaching Staff}

The admission expansion several years ago results in the shortage of teaching staff, the integral level of which remains to be improved. Teachers of emerging specialties are from the majors of fines arts or computer. The quality of students cannot be guaranteed for some emerging private colleges or local colleges with small scale.

\section{E. Training Mode}

Universities frequently communicate with each other on talent education and training mode. Therefore, the talent training modes are similar between different universities, lacking characteristics, clear development direction and close relationship with social needs. The talent training cannot reach the expected goal.

\section{F. Training Objective}

More than ten artistic colleges or universities providing art major in Liaoning are investigated. It shows nearly $60 \%$ of colleges devote to training applied talents; $20 \%$ train compound talents; $15 \%$ train skilled talents and 5\% train academic talents. Some universities have carried out the reform of innovative talent training. The art major in Liaoning province has the correct orientation of talent training.

\section{FACTORS INFLUENCING THE ARTISTIC INNOVATIVE TALENT TRAINING}

The talent training is huge and complicated. The training and education of artistic innovative talents is no exception, influenced by many factors, including the personal factors of students, policy and system, school management, atmosphere of art learning and social environment. Meanwhile, it has close relationship with local culture and economy. At present, although the cultural creative industry of Liaoning is emerging, it develops very fast and has requirements for a lot of talents. Talents trained in universities far from meet the demands of companies and enterprises. The quality of innovative talents cannot meet the increasing demands of cultural industry, which is one of the main reasons to restrict the rapid development of cultural creative industry in Liaoning province.

The training of artistic innovative talents is affected by many factors, which relate to each other. According to the investigation on students in artistic colleges of Liaoning province, it shows the most important factor is students' learning interests. If students are not so interested in learning and professional skills, it is hard for teachers to stimulate their initiative and enterprise of innovative learning, let alone realizing the talent training through the strength of universities.

According to the investigation, the factors closely linked to the innovative talent training mainly include students' learning interests, the consciousness of innovative development and 
teachers' educational level, which have close relationships. So the innovative talent training should start from the three aspects.

\section{FACTORS OF ARTISTIC INNOVATIVE TALENT TRAINING}

After visiting and investigating enterprises of cultural innovation and different types of universities, we deeply realize the training and education of innovative talents and artistic talents' innovation ability is all-round, multidimensional and multi-layered.

\section{A. Professional Skill Is the Basis}

The solid professional knowledge and ability is one of the primary standards for enterprises in the employment as well as the foundation for artistic talents to survive in the society. Enterprises of culture and art pay attention to the solid professional basic knowledge and skills and the broad view of employees.

\section{B. The Multi-disciplinary Knowledge Structure Is Crucial}

The cultural creative industry involves many disciplines. Single talents only knowing the technology are not qualified. They must grasp knowledge like management, operation, humanity and information. The cultural creative industry needs compound talents with different discipline backgrounds and knowledge.

\section{Innovation Ability Is the Soul}

According to the investigation, more enterprises of Liaoning province begin to realize the importance of innovation ability for the development. The innovation consciousness is the core of innovation ability, referring to the idea paying attention to and implementing innovation, involving the curiosity for unknown things and the ability to doubt and think independently. It is the basis of innovation activities and achievements.

\section{Strategies to Train InNOVATIVE ARtistic TALENTS IN UNIVERSITIES OF LIAONING PROVINCE}

Under the social environment of culture creativity at present, the training of innovative artistic talents in universities of Liaoning province should be carried out through:

\section{A. Adapt to Social Needs}

At present, most art majors in Liaoning province are restricted to enroll students. In reality, the cultural industry of Liaoning just starts and urgently needs excellent talents. We cannot take a part for the whole and equate the employment rate to the specialty counterpart rate. The teaching reform should adapt to the social needs. Many specialties have been provided for many years, only paying attention to the professional field instead of the social needs. Talent training cannot only pay attention to the original courses but meet the social requirements. For example, many graduates of the animation major work on animation design in the fields like film and television, game, new media and cultural media are not reckoned in the employment rate of animation major, which is extremely unreasonable. Specialties with obvious advantages in application should not be restricted in enrolling students. They should expand the enrollment proportion according to the market needs, so as to develop the products and the enterprises of culture creativity.

\section{B. Transform Educational Concepts}

Highlight personality. In the education and training of artistic innovative talents, schools and teachers should pay attention to the development of students' independent personality. Personality mainly means centering on students, respecting the differences between different people and stimulating students' potential, making the art learning into the platform for students' growth and progress through artistic creation.

Promote the generalization. The artistic innovative talent training should integrate professional basic education with professional ability training and innovation ability shaping and let students learn comprehensive knowledge and build integrated ability, in order to better train students' innovation ability and consciousness.

Innovate in the teaching model. New teaching models should be excavated by art majors according to the characteristics. For example, many universities are implementing the studio teaching system or explore new forms of curriculum provision and use the flipped classroom. Teachers should improve cultural accomplishments and broaden students' horizon through art, culture and creativity, stimulate their innovation potential and train the innovation ability. Strengthen the team construction of double professionalized teachers or invite enterprise mentors to form teaching team. The school, studio and enterprises cooperate to let students participate in the project of cultural industry, lead them hold or take part in the competition and activities of the cultural entrepreneurship as well as attend lectures, in order to enhance their ability of culture creativity and the level of art and design.

\section{Set Up the Innovative Ideas}

Innovation is the everlasting motive power of artistic development and the continuous pursuit of artistic progress. The core of cultural creative industry is the artistic innovation, which depends on the innovation consciousness and ability and relates to the creative spirit and thinking. With the rapid development of cultural creative industry, as the primary platform for artists and art practitioners to learn and receive education, universities must take the initiative to train the comprehensive innovative artistic talents.

It has a unique meaning for art major to train the innovative talents. Art is a field pursuing innovation. Innovation is the power of art. Culture is the connotation of art. Excellent talents with creative spirit and cultural connotation can be trained through innovation. Innovation atmosphere should be created through competition, cultural festival and art festival as well as student club to train students' innovation consciousness and then lay a solid foundation for the innovative talent training. 


\section{Establish the Evaluation System}

The corresponding effective talent evaluation system can be established through analyzing the development requirements of the cultural creative industry. It consists of cultural and creative enterprises, college students and teachers under the management of society. Except for the evaluation on the classroom performance and test scores, more attentions should be paid to the artistic works and cultural creation. Schools should encourage students to present works, find inspiration in the practice and create more excellent artistic works, comprehensively evaluating them through the popularity and the meaning on cultural construction. More scientific and normative evaluation system should be established in art colleges because of the different standard of talent training from ordinary universities.

\section{CONCLUSION}

In a word, universities in Liaoning still have a long way to go in training innovative artistic talents. Because of problems like the backward training mode, the unsound evaluation system and the poor construction of teaching staff, it is necessary for universities in Liaoning to analyze the environment of culture creativity, adjust the training mode and take effective measures, in order to provide high quality talents for the continuous development of cultural creative industry of Liaoning.

\section{REFERENCES}

[1] Huangfu Xiaotao, New Discussion on the Cultural Industry [M], Changsha: Hunan People's Publishing House, Apr. 2007

[2] Huang Kunjin. General Education of American Universities [M], Beijing: Peking University Press, Jul. 2008

[3] Qi Shuyu. Research on the Development Strategy of Chinese Cultural Industry [M], Beijing: Social Sciences Academic Press, Sept. 2008

[4] Li Wuwei, Wang Huimin. New Discussion on the Creative Industry [M], Shanghai: Orient Publishing Center, Jan. 2009

[5] Ma Geng. Discussion on the Building of Training Mode for Innovative Talents of Art and Design [J], Chinese Art, Jan. 2010

[6] Ran Yu, Discussion on the Innovative Artistic Talents of Higher Art Education [J], Art Panorama, Apr. 2010

[7] Wang Renyong. Discussion on the Innovative Artistic Talents of Art Major in Universities [J], School Party Building and Ideological Education, Nov. 2009

[8] Gu Yanbin. Exploration and Practice of Training Mode for Innovative Talents of Art and Design [J], Decoration, Nov. 2005 